\title{
Periodical Cicada Detritus Impacts Stream Ecosystem Metabolism
}

\author{
Holly L. Menninger,${ }^{1,4 *}$ Margaret A. Palmer, ${ }^{2}$ Laura S. Craig, ${ }^{1}$ \\ and David C. Richardson ${ }^{3}$
}

\begin{abstract}
${ }^{1}$ Behavior, Ecology, Evolution, and Systematics Program, University of Maryland, College Park, Maryland 20742, USA; ${ }^{2}$ Chesapeake Biological Laboratory, University of Maryland Center for Environmental Science, Solomons, Maryland 20688, USA; ${ }^{3}$ Marine, Estuarine, and Environmental Science Program, University of Maryland, College Park, Maryland 20742, USA; ${ }^{4}$ Invasive Species Research Institute, Cornell University, Fernow Hall, Ithaca, New York 14853, USA
\end{abstract}

\begin{abstract}
The emergence of 17-year periodical cicadas in Maryland, USA, in 2004 provided a unique opportunity to study the effect of a large, but temporally limited, resource pulse of arthropod detritus on stream ecosystem function. Cicada emergence was quantified in the forests adjacent to two small streams with different histories of riparian disturbance (Intact and Disturbed sites). We estimated the input of cicada detritus to the streams, described its retention and breakdown dynamics, and measured whole-stream respiration over the cicada flight season (May-July). Average emergence density was significantly greater at the Intact site, but average cicada detritus input rates were greater at the Disturbed site. Cicada detritus was locally retained within both streams and rapidly broke down. Daily whole-stream respiration $\left(\mathrm{CR}_{24}\right)$ at both sites responded dramatically to the cicada pulse, with $\mathrm{CR}_{24}$ doubling pre-cicada mea-
\end{abstract}

surements following the period of greatest cicada input (Intact: $12.82 \rightarrow 23.78 \mathrm{~g} \mathrm{O}_{2} \mathrm{~m}^{-2} \mathrm{~d}^{-1}$; Disturbed: $\left.2.76 \rightarrow 5.77 \mathrm{~g} \mathrm{O}_{2} \mathrm{~m}^{-2} \mathrm{~d}^{-1}\right) . \mathrm{CR}_{24}$ returned to baseline levels when cicada input decreased at the Intact site, but more than doubled again at the Disturbed site $\left(13.14 \mathrm{~g} \mathrm{O}_{2} \mathrm{~m}^{-2} \mathrm{~d}^{-1}\right)$, despite a decline in cicada input rate. Differences in respiration response may be a function of differences in cicada input rates as well as differences in microbial community activity. The strong effects on stream ecosystem function exerted by a short but intense input of periodical cicada detritus may provide insights regarding the response of streams to other irregular resource pulses.

Key words: allochthonous inputs; subsidy; resource pulse; periodical cicadas; ecosystem function; Magicicada; community respiration.

\section{INTRODUCTION}

Inputs of nutrients, detritus or prey from an adjacent donor ecosystem are critical to the ecosystem dynamics of a number of recipient systems (Polis and others 1997), including systems as diverse as

Received 2 April 2008; accepted 21 August 2008

HM, MP, LC, and DR conceived and designed study; HM, LC, and DR performed research; HM, LC, and DR analyzed data; HM, MP, LC, and DR wrote the paper.

*Corresponding author; e-mail: hlm65@cornell.edu desert islands (Polis and Hurd 1995; Anderson and Polis 1999), intertidal zones (Menge and others 2003), and freshwater lakes (Pace and others 2004; Carpenter and others 2005). In eastern deciduous forests of North America, leaf litter entering streams each autumn provides an annual pulse of detritus and nutrients that fuels stream ecosystem processes (Fisher and Likens 1972; Webster and Meyer 1997; Gessner and Chauvet 2002) and structures stream food webs (Wallace and others 1997). Recently, it has been found that the flux of terrestrial invertebrates to streams, occurring 
annually but particularly in the summer months, is important to fish predator diets and leads to trophic interactions that influence stream ecosystem function (Cloe and Garman 1996; Nakano and others 1999; Baxter and others 2004, 2005).

Pulses occurring irregularly or at time scales greater than 1 year may also have major consequences for food web and ecosystem dynamics (Ostfeld and Keesing 2000; Yang and others 2008; Nowlin and others 2008). Acorn masting by oak trees, for example, has been linked to outbreaks of white-footed mice populations that in turn may affect the dynamics of the gypsy moth as well as the incidence of Lyme disease (Ostfeld and others 1996; Jones and others 1998a, b). Large and irregular resource pulses that occur as a result of human activities can have similarly profound impacts on recipient ecosystems; for example, nutrient-laden effluent from a ruptured lagoon holding swine waste in North Carolina induced a 100-fold increase in downstream estuarine algal production (Burkholder and others 1997).

Recent work has suggested that detrital pulses of North American 17-year periodical cicadas (Cicadidae: Magicicada sp.) may have significant effects on ecosystem dynamics. Considered among the most abundant (in number and biomass) of all forest insects (Dybas and Davis 1962), adult periodical cicadas emerge synchronously, quickly satiating predators including birds and small mammals (Karban 1982; Williams and others 1993). Most adults actually die of natural causes 2-6 weeks after emergence and fall from trees as a highquality, highly labile detritus (Williams and Simon 1995; Yang 2004). Yang (2004) examined the effect of this detritus on forest floor processes and found that cicada carcasses increased soil microbial biomass and nitrogen availability, which in turn positively affected the growth and reproduction of understory plants. Using large outdoor mesocosms as surrogates for small woodland ponds, Nowlin and others (2007) reported that inputs of cicada detritus rapidly affected the stability of recipient pond food webs.

Riparian forests have been observed to have among the largest periodical cicada emergence densities, reportedly as high as 370 individuals $\mathrm{m}^{-2}$ (Dybas and Davis 1962). Although Nowlin and others (2007) experimentally manipulated cicada inputs to mesocosms modeled after woodland ponds, no study to date has examined the effects of periodical cicada detritus from riparian forests on adjacent stream ecosystems in situ. In this study, we quantified the 2004 emergence dynamics of Brood X periodical cicadas in the forests adjacent to two streams, estimated the input of cicada detritus to the streams, and described their subsequent retention and in-stream breakdown dynamics. We hypothesized that the large pulse of high resource quality (low C:N) cicada detritus would be readily consumed by in-stream heterotrophs. Consequently, we measured whole-stream community respiration over the course of the adult cicada flight season and predicted that respiration would increase following the input of cicadas. The input of periodical cicadas offers an extraordinary opportunity to record the effect of a large terrestrial arthropod resource pulse on stream ecosystems and may offer unique insights to how similar streams will respond to unexpected resource pulses.

\section{MethodS}

\section{Study Organism}

Seventeen-year periodical cicadas in Brood X (Cicadidae: Magicicada sp.) emerged throughout the Midwest and Mid-Atlantic U.S. in May 2004. The immature cicada nymphs spent the previous 17 years below the forest floor feeding on xylem fluid in tree roots (Marlatt 1907; Brown and Chippendale 1973; White and Strehl 1978; Williams and Simon 1995). In early May, nymphs tunneled up to the soil surface and emerged en masse from their individual underground chambers (Heath 1968; Williams and Simon 1995), leaving behind distinct 13-17 $\mathrm{mm}$ diameter holes often surrounded by mud turrets (Dybas and Davis 1962). After molting into winged, sexually mature adults on nearby vertical surfaces (for example, tree trunks), males and females flew to treetops and shrubs where they engaged in boisterous courtship behavior. Following mating, females oviposited in small twigs and branches (Marlatt 1907). Within several weeks, small nymphs hatched from the eggs and fell to the forest floor where they burrowed into the soil and began feeding on root xylem for the next 17 years (Cory and Knight 1937; Williams and Simon 1995).

\section{Study Sites}

We chose two suburban stream sites with different riparian forest characteristics and histories of disturbance to compare in-stream dynamics between locations that differed in expected cicada emergence densities. The streams are located in the Piedmont physiographic province of Montgomery County, Maryland, USA, near Washington DC, and are first-order tributaries of the Northwest Branch, 
Table 1. Characteristics of Intact and Disturbed Sites

\begin{tabular}{lllllll}
\hline Site & $\begin{array}{l}\text { Watershed } \\
\text { size }\left(\mathrm{km}^{2}\right)\end{array}$ & $\begin{array}{l}\text { Stream } \\
\text { discharge }\left(\mathrm{m}^{3} \mathbf{s}^{-1}\right)\end{array}$ & $\begin{array}{l}\text { Stream } \\
\text { width }(\mathrm{m})\end{array}$ & $\begin{array}{l}\text { Stream } \\
\text { depth }(\mathrm{m})\end{array}$ & $\begin{array}{l}\text { Riparian tree } \\
\text { density }\left(\# / 100 \mathbf{m}^{2}\right)\end{array}$ & $\begin{array}{l}\text { Canopy } \\
\text { cover }(\%)\end{array}$ \\
\hline Intact & 3.24 & $0.014( \pm 0.002)$ & $1.54( \pm 0.09)$ & $0.08( \pm 0.01)$ & 11 & $97.42( \pm 0.59)$ \\
Disturbed & 4.01 & $0.044( \pm 0.004)$ & $2.00( \pm 0.14)$ & $0.20( \pm 0.01)$ & 0.3 & $94.01( \pm 1.23)$
\end{tabular}

Where listed, mean \pm standard error measured during study period, May-July 2004.

a larger stream in the Chesapeake Bay watershed. The first study site, hereafter the "Intact" site $\left(39^{\circ}\right.$ $4^{\prime} 57^{\prime \prime}, 77^{\circ} \mathrm{l}^{\prime} 26^{\prime \prime}$ ) drains a $3.24 \mathrm{~km}^{2}$ watershed (Table 1). The Intact site has an extensive riparian forest that has been undisturbed for at least the last 17 years due to proactive conservation efforts (Moore and Palmer 2005). This mature secondary forest has a tree density of 11 trees per $100 \mathrm{~m}^{2}$, dominated by sycamore (Platanus occidentalis L.) and tulip poplar (Liriodendron tulipifera L.), with a thick understory of sassafras (Sassafras albidum Nutt.). After leaf-out, canopy cover above the stream is approximately $97 \%$.

The "Disturbed" site $\left(39^{\circ} 7^{\prime} 12^{\prime \prime}, 77^{\circ} 0^{\prime} \quad 32^{\prime \prime}\right)$ drains a slightly larger watershed $\left(4.01 \mathrm{~km}^{2}\right)$, but has a much narrower riparian zone, limited largely to one side of the stream and consisting of tulip poplar (Liriodendron tulipifera L.), black cherry (Prunus serotina Ehrh.), and pin oak (Quercus palustris Muenchh.) in a low density of 0.3 trees per $100 \mathrm{~m}^{2}$. Despite the narrow riparian zone, the stream is approximately $94 \%$ covered by the forest canopy after leaf-out. Portions of the riparian forest were removed in 2002 to create a vehicle access point for nearby construction. In addition, in 2003, as part of a wetland mitigation project, much of the soil adjacent to one side of the narrow riparian forest was excavated and transported offsite. Regrowth in this area consists of young riparian trees including green ash (Fraxinus pennsylvanica Marsh.), sycamore (Platanus occidentalis L.), red maple (Acer rubrum L.), box elder (Acer negundo L.), pin oak (Quercus palustris Muenchh.), swamp white oak (Quercus bicolor Willd.), black willow (Salix nigra Marsh.), red osier dogwood (Cornus sericea L.), speckled alder (Alnus rugosa L.), and tulip poplar (Liriodendron tulipifera L.) which were planted in 2003 (Joe Berg, Biohabitats Inc., Personal Communication).

Although we use the terms "Intact" and "Disturbed" both to describe and identify our sites, we advise against extending the results of this study to other streams with similar riparian forest characteristics as our results technically apply only to our two study streams (Hurlbert 1984). Intensive sampling of more than two streams was impossible because of the short cicada flight season and rigorous methods necessary to measure stream ecosystem function; however, we were able to replicate sampling over time within our study sites (Stewart-Oaten and others 1986). We suggest, like Carpenter (1989), Oksanen (2001), and Cottenie and De Meester (2003), that despite the limited number of sites, there is value in studying largescale ecosystem experiments.

\section{Cicada Emergence Density}

In April 2004, prior to periodical cicada emergence, four linear transects were randomly established at each site that extended perpendicularly from the stream bank into the riparian forest. Transects extended into the forest on both sides of the stream, and points were marked at 1, 5, 10, and $20 \mathrm{~m}$ from the stream $(n=32)$. Twelve emergence cages were randomly set throughout the riparian forest at each site and were used to determine that periodical cicada emergence commenced 12 May (hereafter, Day 0), and was completed by 24 May 2004 (Day 12). A sampling frame was used to measure the density of emergence holes in a $0.16 \mathrm{~m}^{2}$ area at each point within the transects beginning on Day 12, where special care was taken to remove vegetation and detritus that might obscure holes. Cicada holes are quite distinct from those of other large, burrowing invertebrates and have compact soil walls that remain intact up to 6 months postemergence (Dybas and Davis 1962; Whiles and others 2001). Evidence from our emergence traps corroborated data from previous studies that concluded the density of emergence holes accurately represents emergence density of cicadas where only one cicada emerges from each hole (Dybas and Davis 1962; Whiles and others 2001).

Greater cicada emergence at the Intact site versus the Disturbed site was predicted and tested by comparing emergence density between sites, with distance from the stream as a covariate, using an ANCOVA (Proc Mixed, SAS v. 8.2, SAS Institute Inc., Cary, NC, USA). Emergence data were square- 
root transformed $(x+0.5)$, as recommended by Sokal and Rohlf (1995) for count data to ensure that assumptions of normality and homogeneity of variance were met.

\section{Allochthonous Inputs}

Prior to cicada emergence, four litter traps, one per transect, were deployed in each stream. Traps were constructed from plastic baskets $\left(0.24 \mathrm{~m}^{2}\right)$ that were cable-tied to rebar supports, and elevated approximately $1 \mathrm{~m}$ above the water. Traps collected allochthonous inputs (plant and arthropod) falling into the channel from adjacent banks or overhanging forest canopy. Litter traps were emptied every 5-9 days through Day 55 (6 July 2004). Contents were sorted as periodical cicada, other terrestrial arthropod, or plant material, dried at $60^{\circ} \mathrm{C}$, and weighed to determine rate of allochthonous input $\left(\mathrm{g} \mathrm{DM} \mathrm{m}^{-2}\right.$ day $^{-1}$ ) over eight roughly similar time intervals (Average: 7 days, Range: 5-9 days). Although whole cicada bodies were typically recovered during trap collection, we did occasionally observe severed wings or pieces of abdomen, suggesting some predator or scavenger activity around the traps as reported by Yang (2004). Thus, our measurements of periodical cicada detritus inputs are likely to be conservative estimates of actual allochthonous inputs of cicadas to the streams.

Allochthonous input rates of cicadas, other terrestrial arthropods, and deciduous tree leaf litter were compared between sites over the eight time intervals using mixed model repeated measures ANOVA (Proc Mixed). A spatial power covariance error structure was used for cicada input rates to account for correlations among errors declining exponentially with distance in time and unequal time intervals, and a compound symmetry covariance error structure was used for other terrestrial arthropod and leaf litter input rates (Littell and others 2006). Rates were transformed using a $\log (x)$ or $\log (x+1)$, depending on the presence of 0 values, to ensure that assumptions of normality and homogeneity of variance were met.

\section{In-Stream Cicada Retention}

Field observations suggested that periodical cicadas that fell into the stream, whether dead or alive, floated. Often they became trapped in the shallow sediments and rocks on the edges of the stream and in riffles, or were retained in leaf packs, root wads, and debris dams. To estimate the retention rate of cicadas at the two sites, we employed methods previously used to determine in-stream leaf litter retention rates (Speaker and others 1988; Webster and others 1994; Brookshire and Dwire 2003). We used wetted corks (density $0.203 \mathrm{~g} \mathrm{~cm}^{-3}$ ) as a surrogate for periodical cicadas (density $0.487 \mathrm{~g} \mathrm{~cm}^{-3}$ ) as they closely approximated cicada body size and more importantly, were buoyant. Batches of corks ( $n=800 /$ release) were released into a $60 \mathrm{~m}$ length of stream at each site. After $l \mathrm{~h}$, the distance in length traveled by each retained cork was measured.

The cork retention rate was calculated from the negative exponential decay equation: $T_{d}=T_{0} \mathrm{e}^{-\lambda d}$ where $T_{\mathrm{d}}$ is the proportion of corks still in transport (not retained) at some distance $(d)$ below the release point, $T_{0}=1$, and $\lambda$ is the instantaneous rate of removal of corks from transport per meter, or the retention rate (Young and others 1978; Brookshire and Dwire 2003). The mean transport distance $S_{\mathrm{p}}$ was then calculated by taking the inverse of $\lambda$ ( 1 / $\lambda)$. The cork retention rate $\lambda$ was compared between streams using an ANCOVA to analyze $\ln \left(T_{d}-T_{0}\right)$ as a function of distance as well as the interaction between distance and site (Proc Mixed). $T_{0}$ was fixed to 1 so no intercept was fit for the decay models. Residuals were examined to ensure that data met assumptions of normality and homogeneity of variance.

\section{Cicada Breakdown Dynamics}

To quantify the in-stream breakdown of cicada detritus, "packs" of known-masses of dead cicadas were assembled, and the mass loss of the packs over time due to physical and biological processes was measured using methods adapted from standard methods for measuring leaf litter breakdown in aquatic systems (for example, Petersen and Cummins 1974; Benfield 1996; Swan and Palmer 2004). Dead periodical cicadas were collected from Prince George's, Anne Arundel, and Montgomery counties, Maryland, USA, during peak emergence in late May 2004 and were immediately frozen. Approximately $10 \mathrm{~g}$ of cicadas ( $\sim 20$ individuals) were wetweighed and placed in double-bagged mesh produce bags $\left(8 \times 3 \mathrm{~mm}^{2}\right.$ effective mesh size), secured closed with cable-ties. This mesh size was large enough to allow access to invertebrate consumers and subject detritus to flow, but small enough to hold cicada material (Benfield 1996). At each site, 10 rows of four cicada packs were attached with tent stakes and cable ties to areas of the stream bottom with similar flow environments (mean velocity $\left.=0.19 \mathrm{~m} \mathrm{~s}^{-1} ; \mathrm{SD}=0.07\right)$ on 16 June 2004 (Breakdown day 0).

To calculate the initial dry mass for cicada packs, 10 samples of cicadas were wet-weighed, dried at $60^{\circ} \mathrm{C}$, and re-weighed for dry biomass to determine 
a dry:wet mass conversion factor $(0.46)$. Four cicada packs were collected on breakdown days 1,3 , $5,12,20,26,33,43,62$, and 98 , beginning with the most downstream rows. Packs were placed immediately on ice and returned to the lab where contents were gently washed and sorted. Cicada pieces were dried at $60^{\circ} \mathrm{C}$ and weighed to determine dry mass remaining.

The breakdown rate $(k)$ was determined using the exponential decay model: $W_{t}=W_{0} \mathrm{e}^{-k t}$ where $W_{0}$ is the initial mass, $W_{t}$ is the mass remaining after time, $t$, and $k$ is the breakdown rate (Petersen and Cummins 1974; Webster and Benfield 1986). To estimate and compare breakdown rates between sites, we used an ANCOVA to analyze $\ln \left(W_{t}-W_{0}\right)$ as a function of day, site, and the interaction between day and site (Proc Mixed). Initial dry mass was fixed so no intercept was fit for the decay models. Residuals were examined to ensure that data met the assumptions of normality and homogeneity of variance. In addition, we calculated the average biological turnover time $T_{\mathrm{b}}$ (days) by taking the inverse of $k(1 / k)$.

\section{Community Respiration}

At each site, community respiration over a $24 \mathrm{~h}$ period was measured once prior to cicada emergence (Day -14) and three times throughout the cicada flight season (Day 12, 26, 40) at each site using the single-station diel oxygen method described by Bott (1996). Dissolved oxygen (DO) concentrations were measured every hour with a MiniSonde multiprobe (Hydrolab, Austin, TX, USA) for $24 \mathrm{~h}$. The net rate of oxygen change due to metabolism was calculated for each 1-h interval, accounting for exchange of oxygen from the stream to the atmosphere using the surface renewal model to empirically derive the reaeration coefficient from stream velocity and depth (Owens and others 1964). The daily rate of community respiration $\left(\mathrm{CR}_{24}\right)$ was calculated by multiplying the average hourly rate of oxygen change over the nighttime hours (22:00-6:00 h) by 24 .

Changes in $\mathrm{CR}_{24}$ were compared on the three dates following cicada emergence to pre-cicada $\mathrm{CR}_{24}$ within each site. Pearson correlation analyses were performed between $\mathrm{CR}_{24}$ and cicada input rate in the time interval just prior to respiration measurements as well as physical factors known to affect respiration (water flow and temperature). Additionally, $\mathrm{CR}_{24}$ at the two focal sites was compared to similar measurements collected in the spring of a non-cicada year (May 2001) from nearby small, forested streams.

\section{Results \\ Cicada Emergence Density}

As predicted, the emergence density in the Intact riparian forest was significantly higher than the Disturbed forest (site: $F_{1,60}=19.05, P<0.0001$ ). On average, there were 25.3 (95\% CI: 18.2-33.4) emergence holes $\mathrm{m}^{-2}$ at the Intact site compared to 5.1 (95\% CI: 2.1-9.1) holes $\mathrm{m}^{-2}$ at the Disturbed site (Figure 1). There was no effect of distance from the stream on emergence density at each individual site (site $\times$ distance: $\left.F_{1,60}=2.16, P=0.15\right)$ or when considering data from both sites combined (distance: $\left.F_{1,60}=0.08, P=0.78\right)$.

\section{Allochthonous Inputs}

The pattern and rate of input of allochthonous material to the Intact and Disturbed sites varied greatly, depending on the type of resource. Significant cicada detritus input rates at each site occurred between 13 and 35 days after the onset of emergence (day: $F_{7,40.2}=21.41, \quad P<.0001$ ) (Figure 2, Table 2), with maximum input rates occurring between Day 21 and 26 at both the Intact site, with $0.349 \mathrm{~g} \mathrm{~m}^{-2} \mathrm{~d}^{-1}$ (95\% CI: $0.223-0.488$ ), and the Disturbed site with $0.575 \mathrm{~g} \mathrm{~m}^{-2} \mathrm{~d}^{-1}(95 \%$ CI: 0.447-0.714). Allochthonous input of cicada detritus to the streams ceased by Day 55 . Across all time intervals combined, the Disturbed site had significantly greater cicada input rates than the Intact site (site: $F_{1,28.9}=5.15, P=0.03$ ), contrasting the observations of lower emergence density at this site compared to the Intact site.

The mean input rates of other terrestrial arthropods to the Intact and Disturbed sites ranged from 0.001 to $0.042 \mathrm{~g} \mathrm{~m}^{-2} \mathrm{~d}^{-1}$, an order of magnitude

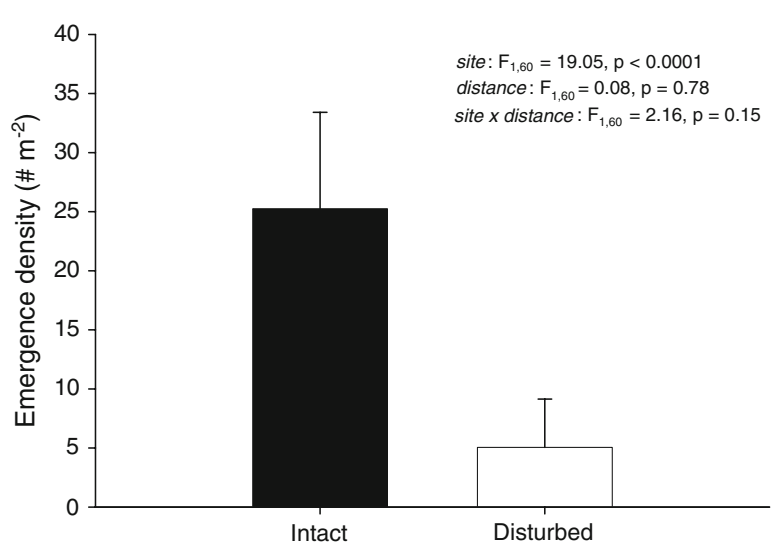

Figure 1. Mean emergence density of Magicicada sp. per $\mathrm{m}^{2}$ based on abundance of emergence holes $(n=32$ per site). Vertical bars indicate $95 \%$ confidence limits. 


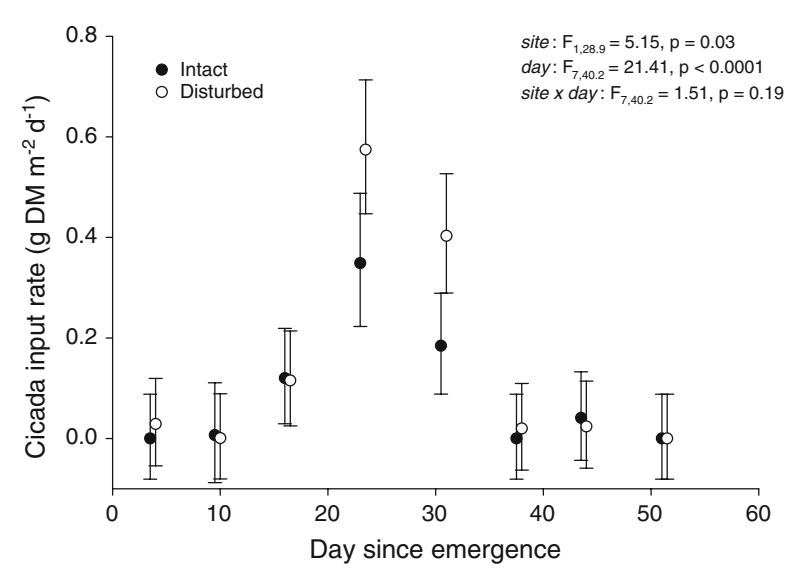

Figure 2. Least-square mean input rates of cicada detritus over time. Rates are calculated over a five to nine day time interval (See Table 2) and plotted at the mid-point of that time interval. Dark circles indicate the Intact site, open circles represent the Disturbed site. Vertical bars indicate $95 \%$ confidence limits. Mean based on $n=4$ litter traps per site.

lower than peak cicada input rates (Figure 3, Table 2) Although input rates generally increased over time (day: $F_{7,39.3}=3.01, P=0.01$ ), there were no differences in rates between the two sites on each sampling date (site $\times$ day: $F_{7,39.3}=1.28$, $P=0.29)$ nor were there overall differences between the two sites (site: $F_{1,5.1}=1.19, P=0.33$ ).

The mean input rates of deciduous tree leaf litter to the Intact and Disturbed sites ranged from 0.114 to $1.162 \mathrm{~g} \mathrm{~m}^{-2} \mathrm{~d}^{-1}$ (Table 2). Leaf litter input rates varied little between sites over the course of cicada emergence (site: $F_{1,5.95}=1.42, P=0.28$; site $x$ day: $\left.F_{7,40}=1.32, P=0.27\right)$ and did not change significantly through time (day: $F_{7,40}=1.20, P=0.32$ ). Generally, mean leaf litter input rates and peak cicada input rates were similar orders of magnitude, and at the Disturbed site, cicada input rate exceeded leaf litter input rates between Days 21 and 35.

\section{In-Stream Cicada Retention}

Patterns of the retention of cicada-surrogate corks conformed well to the negative exponential decay model with $r^{2} \geq 0.90$ for both sites. The cork retention rate $\lambda$ did not differ between the Intact and Disturbed sites (site $x$ distance: $F_{1,62}=0.35$, $P=0.56)$, and data from both sites were combined into a single regression to obtain a mean cork transport distance, $S_{\mathrm{p}}$, of $12.64 \mathrm{~m}(1 / \lambda, \lambda \pm \mathrm{SE}=$ $0.079 \pm 0.003)$. Confirming previous field observations of cicadas at each site, corks were commonly retained by debris dams, root wads, and

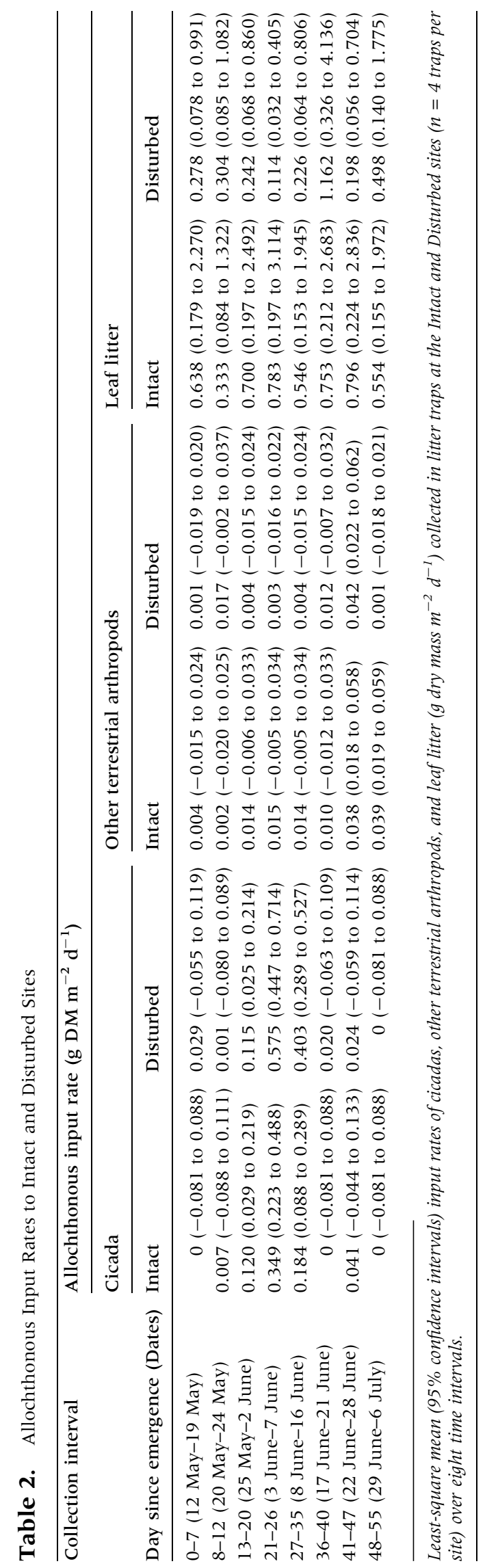



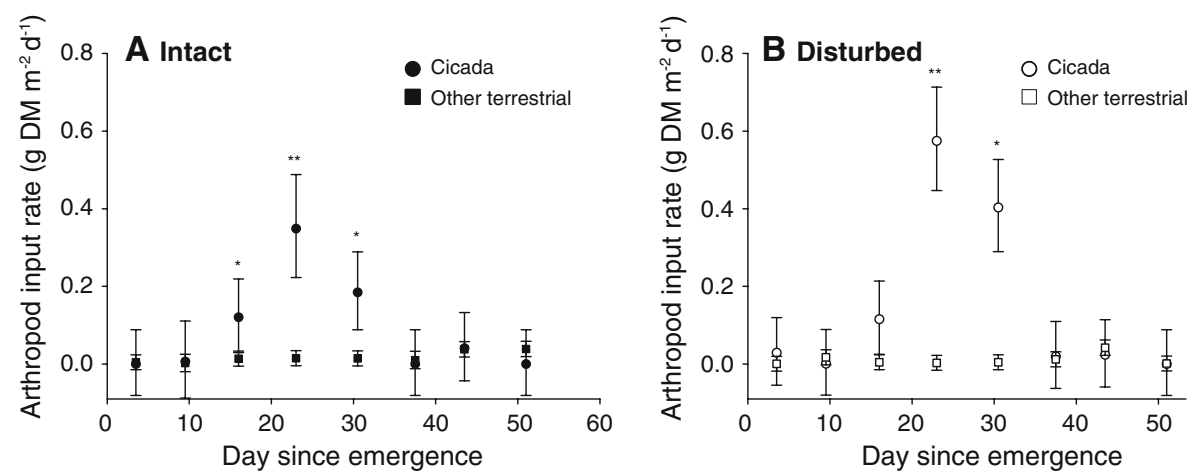

Figure 3. Least-square mean input rates of arthropod dry mass over time at (A) Intact site (dark shapes) and (B) Disturbed site (open shapes). Rates are calculated over a five to nine day time interval (See Table 2) and plotted at the mid-point of that time interval. Circles represent cicada detritus and squares represent other terrestrial arthropods. Vertical bars indicate $95 \%$ confidence limits. $* *$ Indicates significant difference between cicada and other terrestrial arthropod input rates in $t$ test at $P<0.05, *$ indicates $P<0.10$.

overhanging edge vegetation within short distances of release.

\section{Cicada Breakdown Dynamics}

The exponential decay model explained cicada breakdown dynamics well. Decay curves for both sites were highly significant $(P<0.0001)$ and had $r^{2}$ values $\geq 0.79$, but did not differ in the cicada breakdown rate $k$ (day $\times$ stream: $F_{1,58}=0.36$, $P=0.55)$. Data from both sites were combined into a single regression to calculate a mean cicada biological turnover time $T_{\mathrm{b}}(1 / k, k=0.029 \pm 0.002)$ of 34.61 days.

\section{Community Respiration}

Prior to cicada emergence, daily whole-stream community respiration $\left(\mathrm{CR}_{24}\right)$ was four times greater at the Intact site compared to the Disturbed site (Intact: $12.82 \mathrm{~g} \mathrm{O}_{2} \mathrm{~m}^{-2} \mathrm{~d}^{-1}$, Disturbed: $2.76 \mathrm{~g}$ $\mathrm{O}_{2} \mathrm{~m}^{-2} \mathrm{~d}^{-1}$ ). The respiration rate measured at the Disturbed site fell within the range of rates measured during a non-cicada spring at similarly sized streams in nearby watersheds with comparable land uses $\quad\left(0.33-5.08 \mathrm{~g}^{\mathrm{O}} \mathrm{O}_{2} \quad \mathrm{~m}^{-2} \mathrm{~d}^{-1}\right.$, Palmer unpublished data) and within the range measured by other investigators (Bott and others 2006) in headwater streams in the Piedmont region of Pennsylvania (3.11-5.37 $\mathrm{g} \mathrm{O}_{2} \mathrm{~m}^{-2} \mathrm{~d}^{-1}$ ) (Table 3).

Despite initial, pre-cicada differences between respiration rates at the Intact versus the Disturbed site, both sites experienced dramatic increases in $\mathrm{CR}_{24}$ during the cicada flight season (Figure 4). These increases were not correlated with changes in mean stream velocity or average daily temperature $(P \gg 0.05)$. Respiration peaked at $23.78 \mathrm{~g} \mathrm{O}_{2}$
Table 3. Community Respiration and Stream Characteristics at Study and Comparison Sites

\begin{tabular}{lcll}
\hline Site & $\begin{array}{l}\mathrm{CR}_{24} \\
\left(\mathrm{~g} \mathrm{O}_{2} \mathrm{~m}^{-2}\right)\end{array}$ & $\begin{array}{l}\text { Daily } \\
\text { temperature } \\
\left({ }^{\circ} \mathrm{C}\right)\end{array}$ & $\begin{array}{l}\text { Discharge } \\
\left(\mathrm{m}^{3} \mathrm{~s}^{-1}\right)\end{array}$ \\
\hline Intact & 12.82 & 16.5 & 0.021 \\
Disturbed & 2.76 & 13.9 & 0.055 \\
$\mathrm{NWB01}^{1}$ & 0.33 & 18 & 0.005 \\
$\mathrm{NWB18}^{1}$ & 5.08 & 17 & 0.019 \\
PB20 $^{1}$ & 4.20 & 17.4 & 0.003 \\
Hannums $^{2}$ & 3.11 & $>12$ & $0.004-0.020$ \\
Big Springs $^{2}$ & 5.23 & $>12$ & $0.020-0.040$ \\
Moorheads $^{2}$ & 5.37 & $>12$ & $0.007-0.020$
\end{tabular}

Measurements at the Intact and Disturbed sites, prior to cicada emergence (28 April 2004), at ${ }^{1}$ three nearby headwater streams during a non-cicada spring (May 2001, Palmer, unpublished data), and ${ }^{2}$ from forested, headwater streams from the Piedmont region of Pennsylvania (Bott and others 2006).

$\mathrm{m}^{-2} \mathrm{~d}^{-1}$ at the Intact site on Day 26 , increasing nearly two times the pre-cicada rate, but then declined to pre-cicada rates by Day $40\left(11.48 \mathrm{~g} \mathrm{O}_{2}\right.$ $\mathrm{m}^{-2} \mathrm{~d}^{-1}$ ) (Figure 4A). When considered in the context of cicada detritus input rates, $\mathrm{CR}_{24}$ at the Intact site appeared to peak immediately following the interval of greatest input (Day 21-26), and then declined by Day 40. Consequently, there was a significant correlation between the cicada input rate in the interval immediately prior to respiration measurement and $\mathrm{CR}_{24}$ at the Intact site $(r=0.98$, $P=0.02$ ).

Whole-stream community respiration at the Disturbed site also increased following cicada input, but in a different manner than respiration at the Intact site (Figure 4B). Respiration increased exponentially from the pre-cicada measurement 

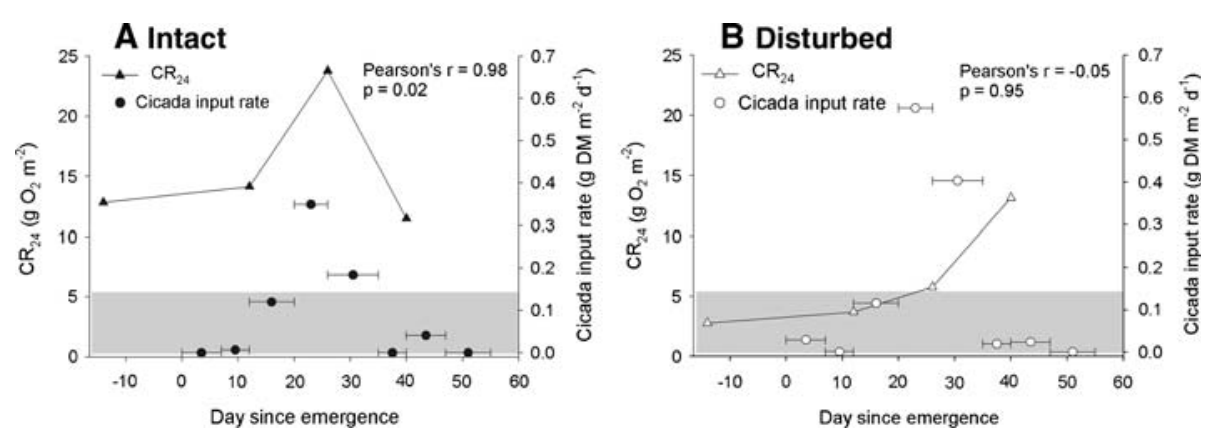

Figure 4. Community respiration $\left(\mathrm{CR}_{24}\right)$ and cicada input rates at the $(\mathbf{A})$ Intact (dark shapes) and $(\mathbf{B})$ Disturbed (open shapes) sites. Triangles represent $\mathrm{CR}_{24}$ measurements (left axis) and circles represent cicada input rate (right axis). Horizontal bars extending from circles indicate the time interval over which cicada input rate was calculated (Table 2). Gray shaded area in each graph represents the range of $\mathrm{CR}_{24}$ measured at headwater Piedmont streams in non-cicada years (see Table 3).

over the course of the cicada flight season, with the highest $\mathrm{CR}_{24}$ on Day $40\left(13.14 \mathrm{~g} \mathrm{O}_{2} \mathrm{~m}^{-2} \mathrm{~d}^{-1}\right)$, over four times the pre-cicada rate. Similar to the Intact site response, $\mathrm{CR}_{24}$ at the Disturbed site increased twofold over the pre-cicada rate following the interval of greatest cicada input (Day 21-26). However, in contrast to the Intact site, $\mathrm{CR}_{24}$ more than doubled again on Day 40, despite a lower cicada input rate. Thus, there was not a significant correlation between cicada input rate and respiration at the Disturbed site $(P=0.95)$.

\section{Discussion}

The emergence of Brood X periodical cicadas from Mid-Atlantic riparian forests in May 2004 and their subsequent fall from the canopy as detritus offered a unique opportunity to study the effects of an intense, nutrient rich terrestrial arthropod pulse on stream ecosystem processes. In this study, periodical cicadas were followed from the time they emerged as terrestrial larvae to the time they entered the stream as detritus, where they were found to have a direct, measurable effect on wholestream community respiration. In fact, community respiration during the cicada flight season was two to four times greater than respiration measured prior to cicada emergence or at other sites during non-cicada years. Moreover, results from a breakdown experiment showed that cicadas were quickly colonized by microbes and invertebrates, suggesting that cicada detritus is indeed a readily used resource in streams.

\section{Cicada Emergence Densities and Input Rates of Cicada Detritus}

The emergence densities of periodical cicadas from suburban Maryland riparian forests in 2004 (Intact:
$25 \mathrm{~m}^{-2}$, Disturbed: $5 \mathrm{~m}^{-2}$ ) were much lower than observations of previous Brood $\mathrm{X}$ emergences in Maryland; these ranged from approximately 76 to 356 cicadas $\mathrm{m}^{-2}$ (Andrews 1921; Cory and Knight 1937; Graham and Cochran 1954). However, these historical estimates were based on density measurements from areas where emergence holes indicated large populations, rather than random sampling of habitat as was performed in this study. Estimates presented here do fall within the range of periodical cicada emergence randomly sampled from riparian forests in Kansas (Whiles and others 2001), but are much lower than the $370 \mathrm{~m}^{-2}$, recorded from random samples in floodplain habitat in a forest preserve in Illinois (Dybas and Davis 1962). These comparisons as well as the large differences in emergence found between the Intact and Disturbed sites, located within just a few miles of one another, suggest that a great deal of variability and patchiness exists in emergence density.

Significantly lower emergence density at the Disturbed site compared to the Intact site was likely the result of riparian forest modification following construction and mitigation in 2002-2003 that would have destroyed critical cicada nymph habitat. Historical records of periodical cicada emergence in New Jersey (Schmitt 1974) and Connecticut (Maier 1982) have indicated that some populations have actually gone extinct as a result of habitat loss inflicted by urbanization. In addition to the direct consequences of deforestation, urbanization contributes to a number of other processes that have profound impacts on forest ecosystems, including the deposition of air pollutants (ozone, sulfur dioxide, nitrogen), the delivery of excess nutrients and chemicals via surface runoff and groundwater contamination, and the invasion of native floras by plant and pest species. Given the cicada nymphal stage is directly tied to the health of 
trees, these other stresses on forest ecosystems may also have significant effects on the emergence and stream input dynamics of the 17-year periodical cicada.

Interestingly, despite lower emergence at the Disturbed site, greater cicada detritus input rates were observed there than at the Intact site. There are several possible explanations for this observation. First, adult periodical cicadas may have been more attracted to the edge habitat provided by the narrow riparian forest at the Disturbed site, as observed by Rodenhouse and others (1997) where males tended to aggregate in the edges of forest fragments to chorus and attract females. Second, the presence of recently planted young trees in the high light mitigation area at the Disturbed site may also have provided preferred oviposition habitat (White 1980; Yang 2006), recruiting females from other nearby areas. A third possibility is that terrestrial predation pressure may have been higher at the Intact site, resulting in fewer adult cicadas falling into the stream as detritus or artificially low estimates of cicada inputs as a result of more carcasses being scavenged from litter traps. We suggest that these explanations are not necessarily mutually exclusive, and it is possible for some or all to be contributing to the observation of lower cicada emergence but greater detritus input rates at the Disturbed site.

\section{Community Respiration Response to Cicada Inputs}

Stream communities rapidly responded to the novel, large pulse of high-quality cicada detritus as shown by the large increases in community respiration $\left(\mathrm{CR}_{24}\right)$ at the Intact and Disturbed sites following cicada inputs (from 12.82 to 23.78 and 2.75 to $13.14 \mathrm{~g} \mathrm{O}_{2} \mathrm{~m}^{-2} \mathrm{~d}^{-1}$ at the Intact and Disturbed sites, respectively). From the retention study we determined that cicadas were retained locally within stream reaches $\left(S_{\mathrm{P}} \sim 13 \mathrm{~m}\right)$, and therefore suggest that the changes we observed in $\mathrm{CR}_{24}$ were the result of local cicada deposition, rather than from the accumulation of inputs upstream. Previous research by Judd and others (2006) has shown that stream microbial communities are quick to adapt to new sources of organic matter, via shifts in both community composition and productivity. Cicada detritus provides a higher quality resource than the leaf litter that also entered the stream during the study period; the C:N ratio of cicada detritus (4.71, Menninger 2007) was much lower than published ratios for the common riparian trees at the Intact and Disturbed sites (29.8-64.7,
Ostrofsky 1997). Pray and others (2008) also report that cicada litter has significantly higher massspecific nitrogen and phosphorous than leaf litter. Consequently, cicada detritus broke down more rapidly $\left(\sim 0.03 \mathrm{~d}^{-1}\right)$ than deciduous tree leaf litter (Webster and Benfield 1986; Ostrofsky 1997).

Colonization by the water mold, Saprolegnia, as well as detritivorous invertebrates (for example, chironomid and tipulid fly larvae) observed when cicada packs were collected and returned to the laboratory, further suggest that cicadas were used as an in-stream food resource by stream biota. These results are also consistent with the findings of Nowlin and others (2007) who observed significantly higher biomass of planktonic and benthic organisms in mesocosms receiving cicada detritus.

The increases in $\mathrm{CR}_{24}$ at the Intact and Disturbed sites are almost certainly in direct response to the inputs of the cicadas. It is unlikely that such increases are an artifact of day-to-day variability because these increases exceed changes in wholestream respiration generally found over seasons, between biomes, and even following floods. For example, based on measurements from 13 forested streams, Bott and others (2006) reported average seasonal values of metabolism to go from 2.88 $(\mathrm{SE}=0.38) \mathrm{g} \mathrm{O}_{2} \mathrm{~m}^{-2} \mathrm{~d}^{-1}$ in cold months to 3.57 $(\mathrm{SE}=0.34) \mathrm{g} \mathrm{O}_{2} \mathrm{~m}^{-2} \mathrm{~d}^{-1}$ in warm months. In reviewing data from nine small streams from different biomes, Dodds (2006) found low variability in whole-stream metabolism (especially compared to GPP) with most values falling between 6.7 and $8.3 \mathrm{~g} \mathrm{O}_{2} \mathrm{~m}^{-2} \mathrm{~d}^{-1}$. Uehlinger (2006) found that over a period of 15 years, about $50 \%$ of the variation in whole-stream metabolism could be attributed to season whereas approximately $20 \%$ was related to bed moving spates; in our study, temperature did not change significantly from pre- to post-cicada inputs and no mobilizing events occurred.

The only study that has explicitly examined the possibility of short-term changes in stream metabolism was recently published by Roberts and others (2007). They made continuous measurements of daily ecosystem metabolism for 2 years in a firstorder stream in eastern Tennessee (Walker Branch) and found that both the lowest daily respiration rates and the lowest day-to-day variability in respiration occurred during the summer months. Large changes in daily rates of respiration, observed only during the spring and autumn, coincided with very large storm flows ( $10 \times$ mean discharge) and significant variation in above-stream photosynthetically active radiation prior to leaf emergence and after leaf fall. Increases in respiration over a relatively short period of time and of the magnitude 
observed at the Intact and Disturbed sites did not occur during the summer months in the Walker Branch study.

The magnitude of the response of the heterotrophic community to the pulse of cicada inputs was similar at both the Intact and Disturbed sites, with $\mathrm{CR}_{24}$ increasing by about $10.5 \mathrm{~g} \mathrm{O}_{2} \mathrm{~m}^{-2} \mathrm{~d}^{-1}$ over the course of our study. However, the Disturbed site exhibited a markedly delayed increase in $\mathrm{CR}_{24}$ following inputs of cicada detritus compared to the timing of the increase in $\mathrm{CR}_{24}$ at the Intact site. Although physical factors like water flow and temperature may affect stream metabolic processes (Webster and others 1995; Mulholland and others 2001), neither variation in flow nor temperature explained the pattern in community respiration observed at either the Intact or Disturbed site or the differences between the site responses to cicada inputs. Further, the input rates of other allochthonous resources, terrestrial arthropods, and leaf litter, did not differ between the two sites and, thus, could not explain inter-site variation in respiration.

We hypothesize that deficiencies in organic matter quality or quantity may have initially limited microbial activity at the Disturbed site, as indicated by differences in $\mathrm{CR}_{24}$ between streams prior to cicada emergence. Differences in background environment and prior development of heterotrophic communities may have then, in turn, led to different rates of $\mathrm{CR}_{24}$ response to the cicada pulse at the two sites (Findlay and others 2003). Studies of subsurface microbes in wetlands have suggested that 'priming,' or exposure to pulses of resources (for example, nitrate) over time, results in a subsequent increase in microbial denitrifying activity (Addy and others 2002, 2005; Kellogg and others 2005). Further, Fontaine and others (2007) recently found that the addition of new (fresh) organic material energetically stimulated ("primed") previously inactive soil microbial decomposers. Thus, although the heterotrophic community at the Intact site was already active, it is likely that the community at the Disturbed site had to be primed before mounting a full response to the cicada inputs.

At the Disturbed site, the exponential response in respiration that continued even as cicada input rates declined may have been promoted by the size and duration of the pulse of cicada detritus. Given that cicada detritus was retained locally $\left(S_{\mathrm{P}} \sim 13 \mathrm{~m}\right)$ and had a biological turnover time of about 35 days, we did not expect the increased $\mathrm{CR}_{24}$ response at the Disturbed site to extend more than 40 days beyond cicada emergence. Like
Nowlin and others (2008), we expected that this cicada resource pulse would transmit quickly through the aquatic ecosystem. Ideally, we would have continued measurements of community respiration to capture the eventual and expected decline in $\mathrm{CR}_{24}$ at the Disturbed site that we observed by Day 40 at the Intact site.

\section{Pulsed Inputs as Novel Resources}

Studies examining the ecosystem and food web consequences of large resource pulses into lotic systems have largely been limited to annual pulses of allochthonous matter, namely deciduous leaf litter (Wallace and others 1997; Webster and Meyer 1997) and spawning anadromous fishes (Garman and Macko 1998; Naiman and others 2002; Zhang and others 2003). Terrestrial invertebrates falling from overhanging riparian vegetation into streams have received significant attention as a prey resource for stream fish (Baxter and others 2005). However, beyond the indirect effects that terrestrial invertebrates have been found to have on ecosystem processes via fish diet shifts, no study to date has examined the direct impact of terrestrial insect subsidies on stream ecosystem function. The large pulse of highly labile cicada detritus dominated inputs into the Intact and Disturbed streams and resulted in dramatic and rapid increases in wholestream community respiration at both sites. The findings we report here add to the growing body of ecological literature on the effects of irregular, but natural, resource pulses on ecosystem processes (Ostfeld and Keesing 2000; Yang 2004; Nowlin and others 2008; Yang and others 2008). Indeed, the stream ecosystem response to the cicada pulse-unique for its timing, size, and quality of detritus-may lend insight for understanding responses to other irregular stream pulses, such as those that may accompany pest outbreaks (for example, gypsy moths) or even human activities (for example, dumping yard and lawn waste, sewer line leaks) in watersheds.

\section{ACKNOWLEDGMENTS}

We thank members of the Palmer Stream Ecology Laboratory for their invaluable assistance with research design and fieldwork, particularly Brooke Hassett, Bob Smith, Chris Patrick, Jen Morse, Kat Cappillino, Matt Reardon, and Roshan Randeniya. We thank Andy Baldwin, Bob Denno, Irv Forseth, Bill Lamp, Mike Vanni, and the anonymous reviewers for suggestions that greatly improved earlier versions of this manuscript. This research was supported by a grant-in-aid from the Wash- 
ington, DC Cosmos Club Foundation to HLM and an EPA STAR award (R828012) and NSF Award (DEB 9741101) to MAP. Contribution 4221 of the University of Maryland Center for Environmental Science.

\section{REFERENCES}

Addy K, Gold A, Nowicki B, McKenna J, Stolt M, Groffman P. 2005. Denitrification capacity in a subterranean estuary below a Rhode Island fringing salt marsh. Estuaries 28:896-908.

Addy K, Kellogg DQ, Gold AJ, Groffman PM, Ferendo G, Sawyer C. 2002. In situ push-pull method to determine ground water denitrification in riparian zones. J Environ Qual 31:1017-24.

Anderson WB, Polis GA. 1999. Nutrient fluxes from water to land: seabirds affect plant nutrient status on Gulf of California islands. Oecologia 118:324-32.

Andrews EA. 1921. Periodical cicadas in Baltimore, Md. Sci Mon 12:310-29.

Baxter CV, Fausch KD, Murakami M, Chapman PL. 2004. Fish invasion restructures stream and forest food webs by interrupting reciprocal prey subsidies. Ecology 85:2656-63.

Baxter CV, Fausch KD, Saunders WC. 2005. Tangled webs: reciprocal flows of invertebrate prey link streams and riparian zones. Freshw Biol 50:201-20.

Benfield EF. 1996. Leaf breakdown in stream ecosystems. In: Hauer FR, Lamberti GA, Eds. Methods in stream ecology. San Diego: Academic Press. p 579-89.

Bott TL. 1996. Primary productivity and community respiration. In: Hauer FR, Lamberti GA, Eds. Methods in stream ecology. San Diego: Academic Press. p 533-56.

Bott TL, Newbold JD, Arscott DB. 2006. Ecosystem metabolism in Piedmont streams: reach geomorphology modulates the influence of riparian vegetation. Ecosystems 9:398-421.

Brookshire ENJ, Dwire KA. 2003. Controls on patterns of coarse organic particle retention in headwater streams. J North Am Benthol Soc 22:17-34.

Brown JJ, Chippendale GM. 1973. Nature and fate of nutrient reserves of the periodical (17 year) cicada. J Insect Physiol 19:607-14.

Burkholder JM, Mallin MA, Glasgow HB Jr, Larsen LM, McIver MR, Shank GC, Deamer-Melia N, Briley DS, Springer J, Touchette BW, Hannon EK. 1997. Impacts to a coastal river and estuary from rupture of a large swine waste holding lagoon. J Environ Qual 26:1451-66.

Carpenter SR. 1989. Replication and treatment strength in whole-lake experiments. Ecology 70:453-63.

Carpenter SR, Cole JJ, Pace ML, Van de Bogert M, Bade DL, Bastviken D, Gille CM, Hodgson JR, Kitchell JF, Kritzberg ES. 2005. Ecosystem subsidies: terrestrial support of aquatic food webs from ${ }^{13} \mathrm{C}$ addition to contrasting lakes. Ecology 86:2737-50.

Cloe WW, Garman GC. 1996. The energetic importance of terrestrial arthropod inputs to three warm-water streams. Freshw Biol 36:105-14.

Cory E, Knight P. 1937. Observations on brood X of the periodical cicada in Maryland. J Econ Entomol 30:287-94.

Cottenie K, De Meester L. 2003. Comment to Oksanen (2001): reconciling Oksanen (2001) and Hurlbert (1984). OIKOS 100:394-6.

Dodds WK. 2006. Eutrophication and trophic state in rivers and streams. Limnol Oceanogr 51:671-80.
Dybas HS, Davis DD. 1962. A population census of seventeenyear periodical cicadas (Homoptera:Cicadidae: Magicicada). Ecology 43:432-44.

Findlay SEG, Sinsabaugh RL, Sobczak WV, Hoostal M. 2003. Metabolic and structural response of hyporheic microbial communities to variations in supply of dissolved organic matter. Limnol Oceanogr 48:1608-17.

Fisher SG, Likens GE. 1972. Stream ecosystem-organic energy budget. BioScience 22:33-5.

Fontaine S, Barot S, Barre P, Bdioui N, Mary B, Rumpel C. 2007. Stability of organic carbon in deep soil layers controlled by fresh carbon supply. Nature 450:277-9.

Garman GC, Macko SA. 1998. Contribution of marine-derived organic matter to an Atlantic coast, freshwater, tidal stream by anadromous clupeid fishes. J North Am Benthol Soc 17:277-85.

Gessner MO, Chauvet E. 2002. A case for using litter breakdown to assess functional stream integrity. Ecol Appl 12:498-510.

Graham C, Cochran AB. 1954. The periodical cicada in Maryland in 1953. J Econ Entomol 47:242-4.

Heath JE. 1968. Thermal synchronization of emergence in periodical 17-year cicadas (Homoptera, Cicadidae, Magicicada). Am Midl Nat 80:440-8.

Hurlbert SH. 1984. Pseudoreplication and the design of ecological field experiments. Ecol Monogr 54:187-211.

Jones CG, Ostfeld RS, Richard MP, Schauber EM, Wolff JO. 1998. Chain reactions linking acorns to gypsy moth outbreaks and Lyme disease risk. Science 279:1023-6.

Jones CG, Ostfeld RS, Richard MP, Schauber EM, Wolff JO. 1998. Mast seeding and Lyme disease. Trends Ecol Evol 13:506.

Judd KE, Crump BC, Kling GW. 2006. Variation in dissolved organic matter controls bacterial production and community composition. Ecology 87:2068-79.

Karban R. 1982. Increased reproductive success at high-densities and predator satiation for periodical cicadas. Ecology 63:321-8.

Kellogg DQ, Gold AJ, Groffman PM, Addy K, Stolt MH, Blazejewski G. 2005. In situ ground water denitrification in stratified, permeable soils underlying riparian wetlands. J Environ Qual 34:524-33.

Littell RC, Milliken GA, Stroup WW, Wolfinger RD, Schabenberber O. 2006. SAS for mixed models. 2nd edn. Cary (NC): SAS Institute, p 814.

Maier CT. 1982. Abundance and distribution of the seventeenyear periodical cicada, Magicicada septendecim (Linnaeus) (Hemiptera: Cicadidae-Brood II), in Connecticut. Proc Entomol Soc Wash 84:430-9.

Marlatt CL. 1907. The periodical cicada. Bull USDA Bur Entomol 71:1-181.

Menge BA, Lubchenco J, Bracken MES, Chan F, Foley MM, Freidenburg TL, Gaines SD, Hudson G, Krenz C, Leslie H, Menge DNL, Russell R, Webster MS. 2003. Coastal oceanography sets the pace of rocky intertidal community dynamics. Proc Natl Acad Sci USA 100:12229-34.

Menninger HL. 2007. Terrestrial-aquatic linkages in human-altered landscapes [dissertation]. College Park (MD): University of Maryland, p 138.

Moore AA, Palmer MA. 2005. Invertebrate biodiversity in agricultural and urban headwater streams: implications for conservation and management. Ecol Appl 15:1169-77.

Mulholland PJ, Fellows CS, Tank JL, Grimm NB, Webster JR, Hamilton SK, Marti E, Ashkenas L, Bowden WB, Dodds WK, 
McDowell WH, Paul MJ, Peterson BJ. 2001. Inter-biome comparison of factors controlling stream metabolism. Freshw Biol 46:1503-17.

Naiman RJ, Bilby RE, Schindler DE, Helfield JM. 2002. Pacific salmon, nutrients, and the dynamics of freshwater and riparian ecosystems. Ecosystems 5:399-417.

Nakano S, Miyasaka H, Kuhara N. 1999. Terrestrial-aquatic linkages: riparian arthropod inputs alter trophic cascades in a stream food web. Ecology 80:2435-41.

Nowlin WH, Gonzalez MJ, Vanni MJ, Stevens MHH, Fields MW, Valente JJ. 2007. Allochthonous subsidy of periodical cicadas affects the dynamics and stability of pond communities. Ecology 88:2174-86.

Nowlin WH, Vanni MJ, Yang LH. 2008. Comparing resource pulses in aquatic and terrestrial ecosystems. Ecology 89:647-59.

Oksanen L. 2001. Logic of experiments in ecology: is pseudoreplication a pseudoissue? OIKOS 94:27-38.

Ostfeld RS, Jones CG, Wolff JO. 1996. Of mice and mast. BioScience 46:323-30.

Ostfeld RS, Keesing F. 2000. Pulsed resources and community dynamics of consumers in terrestrial ecosystems. Trends Ecol Evol 15:232-7.

Ostrofsky ML. 1997. Relationship between chemical characteristics of autumn-shed leaves and aquatic processing rates. J North Am Benthol Soc 16:750-9.

Owens M, Edwards RW, Gibbs JW. 1964. Some reaeration studies in streams. Air Water Pollut 8:469-86.

Pace ML, Cole JJ, Carpenter SR, Kitchell JF, Hodgson JR, Van de Bogert MC, Bade DL, Kritzberg ES, Bastviken D. 2004. Wholelake carbon-13 additions reveal terrestrial support of aquatic food webs. Nature 427:240-3.

Petersen RC, Cummins KW. 1974. Leaf processing in a woodland stream. Freshw Biol 4:343-68.

Polis GA, Anderson WB, Holt RD. 1997. Toward an integration of landscape and food web ecology: the dynamics of spatially subsidized food webs. Annu Rev Ecol Syst 28:289-316.

Polis GA, Hurd SD. 1995. Extraordinarily high spider densities on islands: flow of energy from the marine to terrestrial food webs and the absence of predation. Proc Natl Acad Sci USA 92:4382-6.

Pray CL, Nowlin WH, Vanni MJ. 2008. Deposition and decomposition of periodical cicadas (Homoptera: Cicadidae: Magicicada) in woodland aquatic ecosystems. J North Am Benthol Soc (in press).

Roberts BJ, Mulholland PJ, Hill WR. 2007. Multiple scales of temporal variability in ecosystem metabolism rates: results of 2 years of continuous monitoring in a forested headwater stream. Ecosystems 10:588-606.

Rodenhouse NL, Bohlen PJ, Barrett GW. 1997. Effects of woodland shape on the spatial distribution and density of 17year periodical cicadas (Homoptera: Cicadidae). Am Midl Nat 137:124-35.

Schmitt JB. 1974. The distribution of brood ten of the periodical cicadas in New Jersey in 1970. J N Y Entomol Soc 82:189-201.

Sokal RR, Rohlf FJ. 1995. Biometry: the principles and practice of statistics in biological research. 3rd edn. New York: WH Freeman, p 887.
Speaker RW, Luchessa KJ, Franklin JF, Gregory SV. 1988. The use of plastic strips to measure leaf retention by riparian vegetation in a coastal Oregon stream. Am Midl Nat 120:2231.

Stewart-Oaten A, Murdoch WW, Parker KR. 1986. Environmental impact assessment: "pseudoreplication" in time. Ecology 67:929-40.

Swan CM, Palmer MA. 2004. Leaf diversity alters litter breakdown in a Piedmont stream. J North Am Benthol Soc 23:1528.

Uehlinger U. 2006. Annual cycle and inter-annual variability of gross primary production and ecosystem respiration in a flood prone river during a 15-year period. Freshw Biol 51:938-50.

Wallace JB, Eggert SL, Meyer JL, Webster JR. 1997. Multiple trophic levels of a forest stream linked to terrestrial litter inputs. Science 277:102-4.

Webster JR, Benfield EF. 1986. Vascular plant breakdown in freshwater ecosystems. Annu Rev Ecol Syst 17:567-94.

Webster JR, Covich AP, Tank JL, Crockett TV. 1994. Retention of coarse organic particles in streams in the southern Appalachian mountains. J North Am Benthol Soc 13:140-50.

Webster JR, Meyer JL. 1997. Organic matter budgets for streams: a synthesis. J North Am Benthol Soc 16:141-61.

Webster JR, Wallace JB, Benfield EF. 1995. Organic processes in streams of the eastern United States. In: Cushing CE, Cummins KW, Minshall GW, Eds. River and stream ecosystems. Amsterdam: Elsevier Science. p 117-87.

Whiles MR, Callaham MA Jr, Meyer CK, Brock BL, Charlton RE. 2001. Emergence of periodical cicadas (Magicicada cassini) from a Kansas riparian forest: densities, biomass, and nitrogen flux. Am Midl Nat 145:176-87.

White J. 1980. Resource partitioning by ovipositing cicadas. Am Nat 115:1-28.

White J, Strehl CE. 1978. Xylem feeding by periodical cicada nymphs on tree toots. Ecol Entomol 3:323-7.

Williams KS, Simon C. 1995. The ecology, behavior, and evolution of periodical cicadas. Annu Rev Entomol 40:269-95.

Williams KS, Smith KG, Stephen FM. 1993. Emergence of 13-yr periodical cicadas (Cicadidae, Magicicada)-phenology, mortality, and predator satiation. Ecology 74:1143-52.

Yang LH. 2004. Periodical cicadas as resource pulses in North American forests. Science 306:1565-7.

Yang LH. 2006. Periodical cicadas use light for oviposition site selection. Proc R Soc B Biol Sci 273:2993-3000.

Yang LH, Bastow JL, Spence KO, Wright AN. 2008. What can we learn from pulses. Ecology 89:621-34.

Young SA, Kovalak WP, Del Signore KA. 1978. Distances traveled by autumn-shed leaves introduced into a woodland stream. Am Midl Nat 100:217-20.

Zhang Y, Negishi JN, Richardson JS, Kolodziejczyk R. 2003. Impacts of marine-derived nutrients on stream ecosystem functioning. Proc R Soc Lond B Biol Sci 270:2117-23. 